\section{DECORATIVE AND HOUSEHOLD UTENSILS IN THE PRODUCT ASSORTMENT OF LVIV EXPERIMENTAL CERAMIC AND SCULPTURE FACTORY: THE ISSUE OF FORMATION}

\author{
Mykhailo Bokotei, \\ https://orcid.org/0000-0001-6186-5700 \\ $\mathrm{PhD}$ in Arts, \\ H. T. Head of Glass Art Chair \\ Lviv National Academy of Arts, \\ Lviv, Ukraine \\ bokotey@gmail.com
}

\section{ДЕКОРАТИВНО-УЖИТКОВИЙ ПОСУД В АСОРТИМЕНТІ ПРОДУКЦІї СКЛОЦЕХУ ЛЬВІВСЬКОЇ ЕКСПЕРИМЕНТАЛЬНОї КЕРАМІКО-СКУЛЬПТУРНОї ФАБРИКИ: ДО ПИТАННЯ ФОРМОТВОРЕННЯ}

\section{Бокотей Михайло Андрійович,} https://orcid.org/0000-0001-6186-5700 кандидат мистецтвознавства, Львівська національна академія мистецтв, Львів, Україна bokotey@gmail.com

\section{Abstract}

The aim of the research is to find out the form-making, artistic-constructive and technological features of small-scale production of Ukrainian glass-making enterprises at the end of the twentieth century on the basis of a separate category of products, namely decorative and household utensils. Research methodology. Methods of diachronic and synchronous description of artistic phenomena, method of formal analysis and synthesis, structural-functional and stylistically typological method as well as interview method are used. Scientific novelty. The article is a part of a scientific study that for the first time in the Ukrainian art studies addresses the problems of design of smallscale production of blown glass producers, in particular in the context of the work of one of the most developed enterprises of the country - Lviv experimental ceramic and sculpture factory. Conclusions. The blown glass manufactory LEKSF, which functioned during the period of 1962-2005, became the focal point for the continuation and development of the traditions of the classical Ukrainian blown glass and the base for the work of glass sculptors from the whole Soviet Union. Actually, in 1989 the international symposiums of blown glass in Lviv, which made it into the history of the world studio movement and had a significant impact on the development of glass making
Анотація

Мета дослідження - виявити формотворчі, художньо-конструктивні та технологічні особливості малотиражної продукції українських підприємств-скловиробників кінця XX ст. на основі окремої категорії виробів - декоративно-ужиткового посуду. Методологія дослідження: використано методи діахронного та синхронного опису мистецьких явищ, метод формального аналізу та синтезу, структурно-функціональний і стилістично типологічний, а також метод інтерв'ю. Наукова новизна. Стаття становить частину наукового дослідження, яке вперше в українському мистецтвознавстві розглядає проблеми дизайну малотиражної гутної продукції вітчизняних скловиробників, зокрема в контексті роботи одного з найбільш розвинених підприємств країни - Львівської експериментальної кераміко-скульптурної фабрики. Висновки. Склоцех ЛЕКСФ, який функціонував упродовж 1962-2005 рр. став осередком продовження та розвитку традицій класичної української гути і базою для роботи художників-склярів з цілого Радянського Союзу. Власне тут у 1989 р. розпочали роботу міжнародні симпозіуми гутного скла у Львові, які увійшли в історію світового студійного руху і мали істотний вплив на розвиток склярства в Україні. На основі аналізу декількох різновидів склопосуду, який 
Деміург: ідеї, технології, перспективи дизайну № 2 (2018)

Demiurge: ideas, technologies, perspectives of design № 2 (2018)

in Ukraine, began to function. On the basis of the analysis of several varieties of glassware, which was replicated during the period of the greatest prosperity of the glassworks of LEKSF during the 1970-1980's, the main typological groups were determined, their formative features, color characteristics and technological aspects of formation and decoration were highlighted. The activities of designers of print production: blown glass masters and professional glass artists, who on equal terms were the authors of industrial designs was also studied. The issue of cooperation between a master and an artist in the context of experience exchange, interpretation of author's ideas and co-authorship is extremely important for the research too.

\section{Key words:}

blown glass, design of glass art, glass enterprises, decorative and household utensils, glass artists, blown glass artists. тиражувався у період найбільшого розквіту склоцеху ЛЕКСФ упродовж 1970-1980-х рр., визначено основні типологічні групи, висвітлено їх формотворчі особливості, колористичні характеристики та технологічні аспекти формування та декорування. Розглянуто також діяльності дизайнерів тиражної продукції: майстрів-гутників і професійних художників склярів, які на рівних умовах були авторами промислових зразків. Важливим для дослідження $€$ також питання співпраці на лінії майстер - художник у контексті обміну досвідом, інтерпретації авторських ідей, співавторства.

\section{Ключові слова:}

гутне скло; дизайн художнього скла; підприємства-скловиробники; декоративно-ужитковий посуд, художники-склярі, майстри-гутники.

Вступ 1 Українська гута - це самобутнє, унікальне явище у світо-
вому мистецтві зі столітніми традиціями та давньою історією. У другій половині XX ст. українське художнє скло перебувало у світлі розквіту і свободи авторської ідеї, розвитку творчого експерименту з матеріалом, технологіями, формотворенням. Синергія культурно-мистецьких процесів, які спричинили поширення в країнах Західної Європи та США міжнародного руху студійного скла не могла не вплинути на розвиток скловиробничої галузі й нашої країни. Знаменним роком для українського сучасного склярства був 1962 р., коли розпочав діяльність цех гутного скла Львівської експериментальної кераміко-скульптурної фабрики (ЛЕКСФ), який згодом став одним з основних осередків виробництва гутних скляних виробів у республіці.

\section{Мета дослідження}

Мета дослідження насамперед полягає у відтворенні, розширеному аналізі та збереженні формотворчих і технологічних особливостей зразків гутної продукції, яка становить вагому частку мистецтва художнього скла України XX ст.

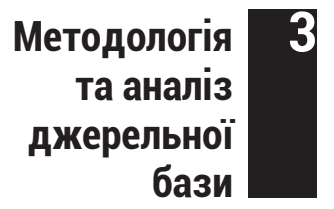

У ході дослідження використано методи діахронного та синхронного опису мистецьких явищ, метод формального аналізу та синтезу, структурно-функціональний і стилістично типологічний, а також метод інтерв'ю.

Одна з важливих груп джерел дослідження - збірки скла, які містяться у фондах музеїв. Опрацьовані музейні збірки дозволили простежити основні тенденції формотворення та поши- 
рення того чи іншого типу скляних виробів. Також це уможливило виокремити основні групи гутних виробів, які продукували місцеві гути, та визначити рівень майстерності гутників. Основним джерелом дослідження продукції ЛЕКСФ стали каталоги зразків склоцеху, до яких вносили всі проекти, впроваджені у тиражування. Технологічні описи виконання зразків зроблено на підставі власного досвіду автора статті, а також інтерв'ю з дизайнерами продукції львівських склопідприємств, колишнім начальником цеху художнього скла ЛЕКСФ Ю. Угрином і головним художником фабрики Ф. Черняком, автором численних проектів А. Бокотеєм.

Результати
дослідження

Історія цеху художнього скла Львівської експериментальної кераміко-скульптурної фабрики тісно пов'язана з Художнім фондом, який був створений у 1944 р. при Спілці художників України. 3 ініціативи керівників Львівської організації СХУ (Я. Чайки, Д. Крвавича та М. Курилича) і фінансової підтримки Худфонду України СХ СРСР у 1962 р. було створено цех гутного скла. На Львівщині у ці часи збереглося покоління професійних майстрів-склодувів, які працювали в гутних цехах невеликих артілей, завдяки чому і вдалося сформувати колектив цеху ЛЕКСФ. Із заснуванням на фабриці гутного цеху діяльність дрібних артілей на Львівщині припинилася, а на ЛЕКСФ перейшли працювати всі провідні майстри-склодуви: Р. Жук, Й. Гулянський, П. Думич, Б. Валько, М. Тарнавський, І. Чабан, О. Гера, Е. Голяк, М. Лопушанський, П. Вдович та інші (Черняк, 2006).

Водночас, істотними були зміни в організації виробництва, де робітники-склодуви на рівні з художниками-професіоналами отримали можливість виконувати зразки для тиражування. Це значно вплинуло на характер продукції, формотворчі та образні особливості. Спільна робота майстрів та художників над розробкою виробничих зразків, освоєння митцями різних технічних і технологічних прийомів сприяли збагаченню художньо-виражальних засобів. Це забезпечило розширення асортименту, підсилення мистецького навантаження, ідейного змісту та декоративної виразності продукції склоцеху львівської фабрики.

Асортимент виробів з гутного скла, який виготовлявся на українських підприємствах цього періоду, за пластичними та утилітарними особливостями можна поділити на три основні групи: побутовий посуд, декоративний посуд, скульптурна пластика. Кількісно найбільшу групу скляної продукції становив побутовий посуд, тобто вироби широкого вжитку. Найбільшими виробниками саме цього виду продукції були Київський завод художнього скла, Львівське виробниче об'єднання «Райдуга», Романівський склозавод, Бережанський, Костянтинівський та інші. Проте, виключно традиційним гутним способом цей вид продукції виготовляли тільки на ЛЕКСФ. 
Деміург: ідеї, технології, перспективи дизайну № 2 (2018)

Demiurge: ideas, technologies, perspectives of design № 2 (2018)

Скористаємось визначенням авторів «Нарисів з історії українського дизайну XX століття» посуду як одного з «найдавніших і найбільших морфологічних структур народного декоративно-прикладного мистецтва, що складається з п'яти родових відмін: господарський, кухонний (для приготування їжі), посуд для столу, посуд для транспортування напоїв і страв, сакральний посуд» (Станкевич, 2012, с. 127). У його виготовленні застосовували найрізноманітніші матеріали. Прикметно, що більшість його форм не змінювалися протягом століть, як і саме приготування традиційних страв. У виготовленні цього посуду витримано усі технічні, утилітарні та мистецькі вимоги. Важливо, що багато його типів стали унікальними творами народного дизайну, а деякі з них без найменшої зміни форми впроваджувалися у промислове виробництво (Станкевич, 2012, с. 127).

У даному дослідженні розглянемо наступні підгрупи виробів, які становили найбільшу частину декоративно-ужиткового посуду з асортименту продукції ЛЕКСФ: декоративні кошики, т. зв. фруктовниці і набори для напоїв. Так як і вази, об'єкти цього виду продукції мали чи не найбільш ужиткове значення і були в кожній домівці.

Вази-кошики, які виготовлялись у склоцеху ЛЕКСФ, базувались на давніх традиціях української гути і якнайкраще зберегли відповідний характер формотворення і декорування ще з XVII-XIX ст. Декоративно-ужиткова скляна вазочка-кошик в історії українського склярства фіґурує неодноразово серед продукції гут Галичини, Волині, Житомирщини, Київщини та інших регіонів України, а їі зразки сьогодні зберігаються у багатьох приватних і державних колекціях. У своїх наукових працях ці вироби згадує Ф. Петрякова (1975, с. 48), Н. Корнієнко (1975), С. Мартинюк (2004, с. 191).

За стилістикою ця категорія виробів склоцеху ЛЕКСФ мала багате оздоблення прозорими або кольоровими наліпами. Зрідка, чаша була прикрашена внутрішнім кольоровим декором. Зазвичай, основу локального кольору було щільно вкрито декоративними наліпами різної форми і конфігурації з перекручуваннями, відтягуваннями та надрізами. Ручка кошика часто була декорована квітками-трояндами угорі, або в місцях приєднання до чаші. Інколи квітка прикрашала також саму чашу кошика. Незважаючи на те, що ці вироби наділені максимальною кількістю рис, які позиціонують їх в категоріях виключно кітчу, вазочки-кошики якнайбільше відповідають цьому стилю. Особливо, враховуючи, що в побуті вони використовувались для цукерок чи печива, або прикрашали вітрини сервантів.

Справжнім майстром цього виду продукції на ЛЕКСФ вважався О. Гера, у чиєму доробку декілька десятків зразків кошиків, виконаних у різні роки. Склодув часто використовував для основи цільне біле сульфідно-цинкове або криолітове скло, декороване хаотичною темною шпіновкою різноманітної конфіґурації (арт. 7670, 7726). У випадку цих зразків майстер вико- 
ристовував для декорування наліпів плоскі траплі', хоча зазвичай вживались фігурні. Обидва кошики поставлені на основу, т. зв. «п'ятак»². Внутрішній контрастний колір першого зразка смарагдовий, а другого - блакитний. Окрім того, колір оптично формує ободок на фіґурному завершенні чаші. Інший зразок з криолітового скла декорований в основі перекрученою кольоровою шпіновкою по всій поверхні, при цьому не закатаною, яка добре зберегла фактуру. Декоративні наліпи виконані з використанням пінцета, а не траплів, у формі завитків, а не площин.

Василь Драчук у притаманному для майстра стилі запроектував зразок з арт. 7681. Основа яскраво-червоного кольору виконана за тим самим принципом, що вази автора: з використанням керика і відтягуванням скломаси. Прозора ручка декорована кольоровою квіткою нагорі і двома квітками в місцях приєднання до чаші.

Іван Чабан використав для двох зразків вазочок-кошиків (арт. 779978000) давній спосіб формування виробу на «п'ятаку». Основа у цьому випадку будується не на базі продувної банки, а способом пошарового накладання скла на плоску круглу площину. Цей метод доволі довготривалий і вимагає неабиякої майстерності склодува при нарощуванні маси і утримуванні при цьому симетрії і рівноваги виробу. Декоративна фактура надана з допомогою фігурних траплів, якими сплющені під кутом паски гарячого скла кожного почергового шару. Ручка перекручена і декорована наліпами, також - фігурними траплями. Перший зразок зроблено з прозорого, натомість, другий з медового скла, яке часто варили у горшковій печі. Якщо у першому кошику декор надавався плоскими рифленими траплями,

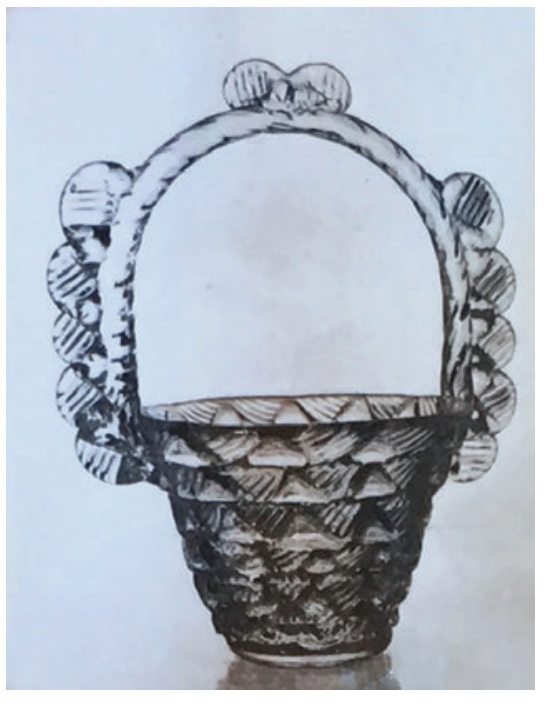

Рис. 4. 1. І. Чабан. Кошик, ЛЕКСФ, 1986 р., арт. №7799.

Гутне скло, вільне формування, $h=26$ см. Фото з каталогу продукції ЛЕКСФ.

Fit. 4.1. I. Chaban. Basket, LEXF, 1986, Art. No. 7799.

Gutna glass, free formation, $h=26 \mathrm{~cm}$. Photo from the catalog of products LEXF.

\footnotetext{
${ }^{1}$ Інструмент для декорування з плоскими або фігурними кінцівками.

2 П'ятак - плоский скляний диск, який накладається на дно виробу під час перекладання на ліпку, переважно з метою підвищення стабільності або полегшення шліфування (у випадку широкої основи).
} 
Деміург: ідеї, технології, перспективи дизайну № 2 (2018) Demiurge: ideas, technologies, perspectives of design № 2 (2018)

то у другому цей прийом виконувався інструментом з півкулями на кінцях - таким, який використовували для формування очей у скульптурній пластиці.

Надзвичайною відповідністю пропорцій та елегантністю доволі стриманого і водночас виразного декору характеризується ваза-кошик авторства І. Мацієвського (арт. 8118). Синя чаша кошика оздоблена грубими наліпами з кольорової крихти у формі квітів на кожній з чотирьох приплюснутих граней. Прозора ручка прикріплена до широко відкритої з відведеними фалдами пелерини. Вінце ручки декороване невеликого розміру кольоровою квіткою. Ця форма з подібним декором виконувалась у різній кольоровій конфіґурації. Видозмінювались також декоративні елементи як чаші, так і ручки кошика.

Наступна, значна за обсягами категорія склопосуду в асортименті ЛЕКСФ - так звані фруктовниці. До цієї групи зараховуємо також інші за призначенням вироби: попільнички, набори для салатів, тарілки. Часто ці форми були доповненням до композиції з вазою, рідше входили в комплект для напоїв. У каталогах асортименту склоцеху львівської фабрики 1970-1980 рр. зустрічаються зразки фруктовниць, виконані фактично всіма майстрами, які в той час працювали на верстаті. Авторами або співавторами зразків зазначаються також такі професійні художники як А. Бокотей, Б. Галицький, С. Мартинюк, Ф. Черняк та ін.

До найяскравіших зразків, виконаних А. Бокотеєм належать фруктовниці, які входили у комплекти з вазами: арт. 6029, 6030, арт. 6420 та арт. 6555, 6558. Перші дві фруктовниці з 1980 р. виконані у максимально класичній формі: одна з рівним краєм, інша - у формі хвилястої пелерини. Декоровані вироби у спосіб, який часто використовував тоді художник при виконанні зразків - імітації венеційської нитки, комбінованої з коричневого та червоного скла.

Характерним за формою та технікою виконання є зразок з арт. 6420, який у комплекті з вазою повністю вирізнявся серед зразків того часу. Мінімалістиний підхід до колористичного рішення, нестандартна форма з відтягненими отворами підкреслюють прагнення автора до творчого експерименту. До речі, це зразковий приклад, коли у каталозі продукції зазначався один автор - майстер-гутник, а фактично дизайнером

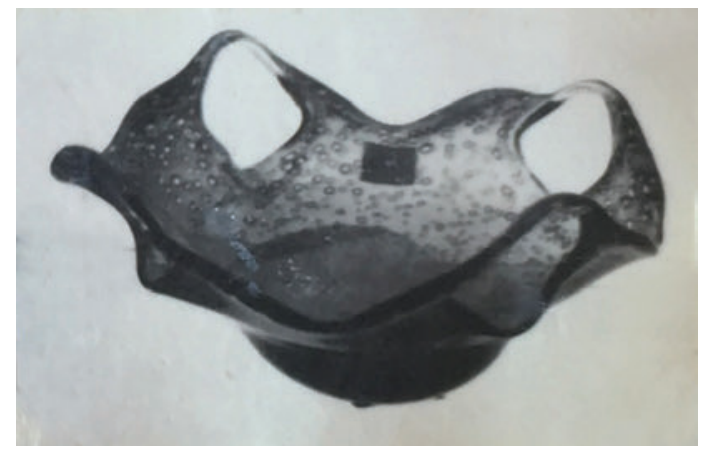

Рис. 4.2. А. Бокотей, І. Мацієвський. Фруктовниця, ЛЕКСФ, 1981 р., арт. №6420. Гутне скло, вільне формування, $D=27$ см. Фото з каталогу продукції ЛЕКСФ.

Fit 4.2. A. Bokotey, I. Matsievsky. Fruktovnica, LEXF, 1981, art. No.6420. Gutna glass, free formation, $D=27 \mathrm{~cm}$. Photo from the catalog of products LEXF. 
був професійний художник: ваза з арт. 6435 в аналогічному стилі і з однаковим способом виконання, записана як виконана І. Мацієвським. Фруктовниця, натомість - у співавторстві з А. Бокотеєм.

Два наступні зразки з арт. 6555, 6558 є частинами комплекту з шести елементів: чотири салатниці різного розміру, ваза на цукерки і попільниця. Автор знову звертається до простих експериментальних форм, де силует побудований на широкій стійкій основі, звуженій згори умовної ніжки і в різній мірі нерівномірно широко відкритим верхом. Форми салатниць повторюються у різних розмірах, цукорниця і попільниця, натомість, відрізняються і пристосовані до утилітарних потреб. Верхня розведена площина попільниці прим'ята у чотирьох місцях для місця на цигарку. У вазі на цукерки характерними є широко відкриті поли, подібно до тарілки. Форма, натомість, стабільно стоїть на широкій монолітній нозі. Важкості і приземленості додатково надає локальний коричневий колір основи виробу. Верхня пелерина кожного з елементів набору інтенсивно декорована товстою венеційською ниткою, подібно до інших зразків А. Бокотея того періоду. При цьому, якщо на салатницях чітко виражена спіраль і проміжки між почерговими пасмами, то у цукерниці ця межа майже зовсім знівельована і шпіновка накладена впритул. Цей хід створює враження, ніби венеційський декор був виконаний у вертикальному напрямку.

Зразки фруктовниць і тарілок зустрічаються і в авторському доробку майстра скульптурної пластики В. Драчука. Десертний набір з арт. 6216 виконаний із півтону абрикосового кольору зі спіралевидною шпіновкою з кольорової крихти. Простота декору відповідає мінімалістичній формі: розведена тарілка у гарячому стані легко опущена вниз, що надає площині нерегулярної хвилястості.

Два різні за характером типи зразків належать авторству М. Павловського. Тарілки з набору для печива, арт. 6384, виконані майстром у 1981 р. Прості форми синьо-зеленого кольору нарочито декоровані відвертими зовнішніми наліпами у вигляді великих «малинок». Додатково, дві з них розміщені на протилежних краях, що спричинило так зване «поведення» форми, коли тарілка деформується у двох напрямках під впливом ваги накладеного близько до набеля скла. Спершу здається, що такий спосіб декорування не зовсім притаманний корифею української гути, та спадщина склодува настільки велика і різноманітна, що у його виробах постійно зустрічаємо пошуки нових шляхів формування і обробки художнього скла.

Наступні зразки, арт. 8014, 8017, виконані у 1986 р. у більш традиційному для майстра стилі з використанням венеційської нитки та мілефіорі. Комплект складався з чотирьох елементів: ваза, цукорниця, тарілка, фруктовниця. Завершення форми кожного з виробів виконане у подібному стилі, проте у відмінних формах: ваза і фруктовниця ліровидної форми мають роз- 
Деміург: ідеї, технології, перспективи дизайну № 2 (2018) Demiurge: ideas, technologies, perspectives of design № 2 (2018)

критий верх, обмежений чорним ободком; цукерниця у формі регулярної кулі має прим'ятий пінцетом у декількох місцях край без ободка; тарілка має рівностінну відкриту форму.

Як і решта зразків Ф. Черняка, який довгий час займав посаду головного художника ЛЕКСФ, фруктовниці і тарілки митця вирізняються понадчасовістю дизайну, елегантною формою і новаторством декору. Три елементи фруктового набору різних розмірів з арт. 5787 виконані в одній формі. Локальний червоний колір легко збитий білим підкладом з сульфідно-цинкового скла. Два протилежні кінці простої відкритої форми відтягнені пінцетом, при чому один - у напрямку назовні, а другий - до середини. Зразок з арт. 6634, знову ж таки, поєднує простоту та лаконічність з витонченістю й елегантністю як форми, так і декору. Білого кольору тарілки з салатного набору оздоблені масивною червоною спіралевидною шпіновкою, стягненою до центру в одному місці. У цьому ж місці форма тарілки легко увім'ята досередини на гарячому виробі в розведеному стані. Схожа техніка застосована у внутрішньому декорі тарілки (арт. 6837), де додатково червона, груба, стягнена у двох протилежних кінцях смуга на прозорій тарілці збагачена внутрішньою павутинкою з синьої цапфи.

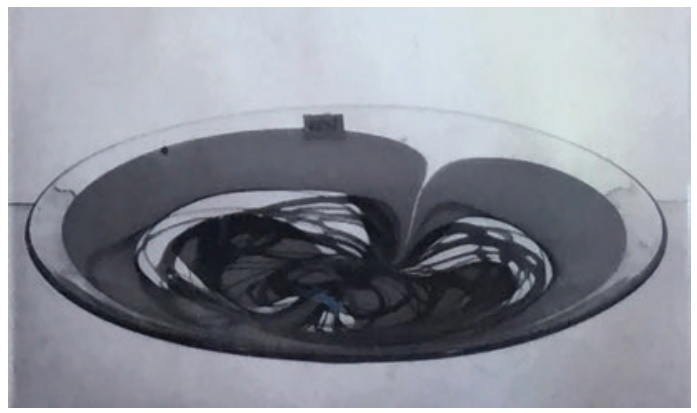

Рис. 4.3. Ф. Черняк. Тарілка, ЛЕКСФ, 1982 р., арт. №6837. Гутне скло, вільне формування, D =35 см. Фото з каталогу продукції ЛЕКСФ.

Fit. 4.3. F. Chernyak. Plate, LEXF, 1982, art. No.6837. Gutna glass, free formation, $D=35 \mathrm{~cm}$. Photo from the catalog of products LEXSF.

у багатьох зразках продукції кінця 80-х років Ф. Черняк застосовує спосіб декорування виробів з використанням продувних накладів гарячого скла. Незважаючи на традиційність цього методу для української гути, у цьому випадку за зовнішніми ознаками цей декор абсолютно не нав'язує класичних зразків. Наклади з гарячого скла майстер розміщує близько до набеля з роздутою банкою і продуває. Згодом, при розведенні вже на ліпці1 по краях формуються оригінальні випуклості, які водночас відтягують поли відкритого виробу у своєму напрямку під дією власної ваги. Такий хід застосовано у фруктовниці арт. 7963 з локальним темним кольором наданим сульфідно-смарагдовим підкладом.

Іван Мацієвський у фруктовниці з арт. 6833 інтерпретував спосіб декорування зразків, впроваджений А. Бокотеєм, де краї

\footnotetext{
1 Ліпка (або «понтія») - непродувна трубка, на яку перечіпляється роздута і відформована банка для розведення або продовження формування.
} 
завершувались відтягнутими проколами. Інша тарілка авторства І. Мацієвського (арт. 8357) у традиційній хвилястій формі густо декорована кольоровою біло-синьою ниткою, а також великими червоними й оранжевими плямами. Цікаво, що інтенсивний кольоровий декор накладався на прозору банку без підкладу.

Ще одним важливим, проте доволі незначним сегментом в асортименті посуду на ЛЕКСФ були подарункові, т. зв. весільні фужери, виконані в стилі середньовічного венеційського скла. Витончені тонкостінні форми чаші, фігурні ніжки, багатий декор з зовнішніми наліпами, формований у різній конфіґурації - все це майстерно виконане нагадувало роботу віртуозів з Мурано. Часто фужери виготовлялись в парі: вищий для молодого, нижчий для молодої. Майстром, який досконало володів венеційською технікою і багато експериментував, щоб досягти бажаного результату і відкрити незнані техніки, був М. Павловський. Проте, в каталогах продукції склоцеху ЛЕКСФ за 70-80 рр. зафіксовано лише роботи, виконані В. Білоусом. При цьому в журналах зазначається авторство Р. Гудими-Білоус, дружини склодува. До речі, такі випадки часто трапляються, особливо коли проект виробу належить професійному художнику, а виконавцем є майстер-гутник. До прикладу, А. Бокотей часто записував зразки на майстра, з яким працював найчастіше - І. Мацієвського, С. Мартинюк - на О. Геру, Б. Галицький - на Р. Жука чи I. Мацієвського та ін. Так відбувалось, насамперед, з фінансових міркувань, оскільки більша кількість зразків у одного автора мала відображення в гонорарах.

Чашу весільного фужера з арт. 7720, виконано з накладом білого сульфідно-цинкового скла. Цільна ніжка, забарвлена грубою крихтою оранжевого кольору, відформована у керику і перекручена з відлитим денцем. Сполучення ніжки і чаші декороване прозорими наліпами з надрізами та завитками.

У наступних зразках стопа фужера виконана у класичний спосіб, методом розведення з допомогою двох складених дощечок. Чаша кубка з арт. 8072 виконана з двох накладів контрастних кольорів: внутрішній -зелений, зовнішній - червоний. Витягнута ніжка декорована двома пелюстками, обробленими траплями. Зовсім інший за формою, з акцентом на великій чаші фіолетово-коричневого кольору, фужер з арт. 8073. Якщо чаша у фужері доволі простої форми, то ніжка складена з трьох окремих частин і декорована завитками. Незважаючи на багатий і складний декор ніжки, оптично за формою переважає чаша.

Абсолютно іншим за характером є фужер з арт. 8074, де основна увага акцентується на декоративному персні, який символізує обручку, з відтягненими наліпами. Перстень у доповнення до витонченої ніжки виконаний з набору сформованого у керику і перекрученого у спосіб, який часто застосовувався у венеційському склі. Червоного кольору чаша приплюснута в основі. 
Деміург: ідеї, технології, перспективи дизайну № 2 (2018)

Demiurge: ideas, technologies, perspectives of design № 2 (2018)

Ще одним виразним зразком у цій категорії продукції $€$ фужер з арт. 8600. Знову ж таки, автори вдаються до збільшеної чаші у формі коктейльного фужера, а ніжка декорована у формі символічного персня, на цей раз цільного і оточеного кольоровою венеційською ниткою червоного кольору. Згори персня накладені перекручені завитки з прозорого скла, які, можливо і зайві, але додають фужеру рис класичної української гути.

Фужер з арт. 8710 декорований у манері з відвертим наслідуванням венеційських зразків. Сполучення ніжки і чаші виконане у формі трьох з'єднаних куль і декоровані символічними драконами, чиї доволі реалістичні голови скоріш нагадують змій. Хоча, це враження нівелює кучерява оздоба тіла, виконана з густо перекрученого прозорого накладу.

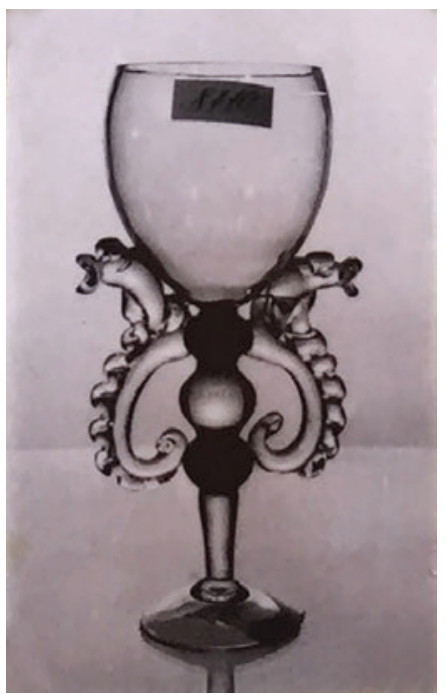

Рис. 4.4. Р. ГУдима, В. Білоус. Келих, ЛЕКСФ, 1988 р., арт. №8710. Гутне скло, вільне формування, $h=26$ см. Фото з каталогу продукції ЛЕКСФ.

Fit 4.4. R. Gudima, V. Belous. Kelih, LEXF, 1988, art. No.8710. Gutna glass, free formation, $h=26 \mathrm{~cm}$. Photo from the catalog of products LEXF.

Чи не наймасштабнішою групою за кількістю зразків у асортименті склоцеху ЛЕКСФ є набори для пиття. Це одна з тих категорій продукції, яка до сьогодні часто експлуатується в українських домівках. Їй притаманна широка колористична гама, розмаїття форм, багатство варіантів цільового призначення та різна кількість елементів у комплектах.

Як і більшість художників, які брали участь у розробці проектів склопосуду на ЛЕКСФ, над зразками наборів для пиття працював А. Бокотей. У серії декоративно-ужиткових об'єктів різного призначення, виконаних автором упродовж 1980 р. з використанням венеційської нитки, художник створив набір з карафки і чарки, арт. 6194. Проста форма прозорої карафки з квадратною основою декорована спіралевидною перекрученою шпіновкою чорно-білого кольору. Чарка рівної округлої форми з легко розведеним вінцем.

Винятковим багатством форми і декору вирізняється набір з арт. 7883, який складається з високої фігурної карафки, виконаної тиходутим способом, та чотирьох чарок на фігурних ніж- 


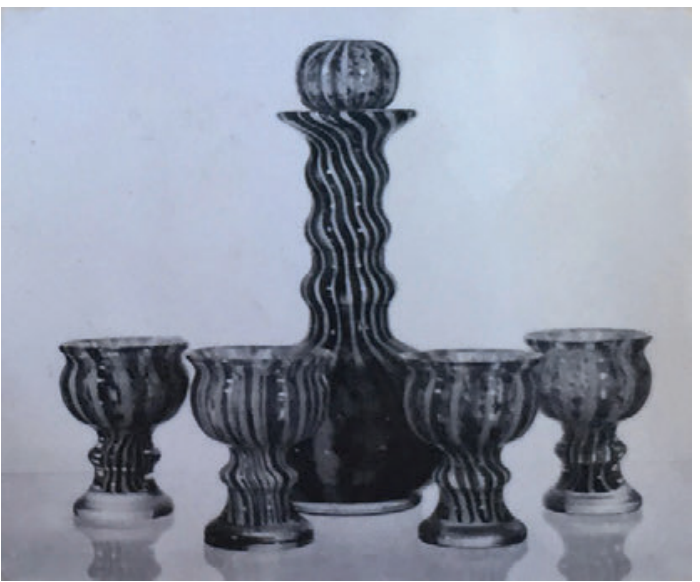

Рис. 4.5. А. Бокотей. Набір для пиття, ЛЕКСФ, 1986 р., арт. №7883. Гутне скло, вільне формування, $h=29 ; 12$ см. Фото з каталогу продукції ЛЕКСФ.

Fit. 4.5. A. Bokotey. A set for drinking, LEXF, 1986, art. №7883. Gutna glass, free formation, $h=29 ; 12 \mathrm{~cm}$. Photo from the catalog of LEXS products.

ках, які за силуетом органічно доповнюють штоф. На зразках помітно виділяється великий прозорий залив. Фіолетово-червона основа елементів набору декорована вертикальною білою ниткою з сульфідно-цинкового скла. Окрім того, біла шпіновка через реакцію з основним кольором має нерегулярний край і надає виробам своєрідної мармурової фактури. Завдяки використанню форми для виконання об'єктів з набору художникові вдалося спрецизувати і витримати досконалі співвідношення «пропорція - розмір», що наділяє даний комплект посуду особливими естетичними рисами і вирізняє його серед інших зразків.

Ще один зразок авторства А. Бокотея виконаний з використанням технології видування у форму і за характером і формальними ознаками якнайкраще асоціюється з призначенням набору - для компоту (арт. 7984). Тут опукла форма дзбанка увінчана широкою розкритою та загнутою з двох боків тарілкою. Завдяки такому експерименту з формою художник надав кшталт носика для наливання не завдяки традиційному відгинанню, а способом деформації цілої розведеної площини горла. Таким чином, виконавши функціональний елемент, автор додатково створив індивідуальний характер та оптичне враження призначення саме для компоту. На відміну від складної форми дзбанка, склянки у комплекті прості, присаджені, з грубим прозорим заливом. Комплект декорований щільно накладеною грубою шпіновкою з крихти синього та білого кольору, додатково «прочесаною» вертикально.

Надзвичайною простотою як форми, так і декору вирізняється комплект авторства Б. Валька з арт. 6001, виконаний у 1979 р. Синя класична форма дзбанка і горнятка з прозорою ручкою декорована технікою «кракле». Виконаний пізніше на-

\footnotetext{
1 Техніка полягає у швидкому зануренні готової банки у воду, а згодом у легкому піддуванні у вікні кухи або печі. При цьому верхній потрісканий набір в силу роздування банки зсередини розходиться і утворюються нерегулярні площинки, прорізані рівчаками.
} 
Деміург: ідеї, технології, перспективи дизайну № 2 (2018)

Demiurge: ideas, technologies, perspectives of design № 2 (2018)

бір для пиття з арт. 6117 доповнює цілий ряд зразків ваз і посуду, спроектованих майстром у подібному стилі з використанням прочесаної у двох протилежних місцях тонкої білої шпіновки на синій основі виробу. Ще іншу техніку склодув застосував у комплекті з арт. 6222, де монотонна основа легкого димчастого кольору декорована у дрібному керику і згодом перекручена, утворивши оптично вигляд спіральної структури.

У проекті Б. Галицького з арт. 5999, виконаному художником наприкінці 1979 р., проста форма циліндричних чарок доповнена карафкою з квадратною основою і округлим корком. Напівпрозора в основі, розтягнута угорі карафка зеленого кольору декорована жовтою спіралевидною шпіновкою. Чарки, натомість, дещо нагадують зразки М. Павловського, виконані на Львівському склозаводі №1 ще до початку роботи склоцеху ЛЕКСФ: монотонна основа декорована щільною тонкою шпіновкою.

Богдан Галицький надавав перевагу високим витонченим формам, при цьому акцентуючи власне на силуеті, а не на декоративному навантаженні. Два наступні комплекти для пиття слугують досконалим прикладом такого підходу автора до проектування склопосуду. Набір з арт. 7859 виконаний з бригадою Р. Жука. Високий дзбанок молочного напівпрозорого кольору декорований у нижній частині продутими мілефіорі. Таким чином декоровані і горнятка, додатково відформовані у керику. Інший комплект, арт. 8368, виконаний з бригадою І. Мацієвського у 1987 р. Ліроподібні склянки і дзбанок з традиційним силуетом декоровані тонкою вертикальною шпіновкою, яка візуально підкреслює надмірне прагнення до акцентування смуклої форми. Молочна напівпрозора основа виробів оздоблена тонкою шпіновкою червоного та смарагдового кольору.

Різні прийоми декорування використовував О. Гера при виконанні наборів для пиття. На відміну від інших майстрів, в різні роки у О. Гери бачимо захоплення зовнішніми наліпами: арт. 5764, арт. 6039, де нескладна форма дзбанка збагачена інтенсивно пропрацьованою короною з прозорого скла; арт. 7817 з символічним рівним пояском навколо форми дзбанка і горняток у місці нижнього кріплення ручки; арт. 6581 з трояндами на чотирьох боках квадратної карафки і декорованим назовні корком. При цьому автор, здавалось би, не ускладнював процесу напруженим і трудомістким внутрішнім декором. Часто використовувалась банальна спіральна шпіновка, тонка вертикальна шпіновка, декоративні плями з крихти, або мілефіорі. Автор рідко вдавався до ускладнених форм виробів, працюючи переважно на основі елементарних класичних кшталтів.

Набір, виконаний В. Драчуком у співавторстві з І. Шуманським у 1979 р. з арт. 5847, створює враження кришталевого об'єкта завдяки масивним накладам з прозорого скла зовні набору. Нескладне декоративне вирішення докорінно змінило візуальне сприйняття простої форми пляшки, яка є в основі. 
Вісім вертикальних наліпів, видимо покладених на «плечиках» банки, повторюються на чарці, створюючи таке ж оптично збагачене враження. При виконанні цього набору використане виключно безбарвне скло, що у свій спосіб підкреслює оптику застосованого ефекту масивних накладів.

Різнопланові шпіновки, - вертикальні, горизонтальні рівні, відтягнуті і прочесані, динамічні діагональні, - часто використовував при проектуванні наборів посуду П. Думич. Т. зв. «павутинка», виконана швидкими рухами від набеля до кінця банки, присутня у наборі для пиття з арт. 6053. Молочна основа виробів покрита тонкою вертикальною нерегулярною синьою ниткою. На елементах комплектів з арт. 6068, 6513 автор застосував грубу й інтенсивну шпіновку темного кольору, рівномірно прочесану догори виробу. Набір для пиття «Півник», арт. 6088, також декорований протягненою горизонтальною шпіновкою, проте тут основний акцент ставиться на декорі ручки, корка і дзьобика, формуючи образ півня.

Бригади більшості майстрів, які були склодувами у цеху ЛЕКСФ, часто працювали з професійними художниками, втілюючи в життя упродовж 70-90-х рр. проекти А. Бокотея, Б. Галицького, С. Мартинюка, 3. Масляк, М. Шимчука, Ф. Черняка та ін. Найчастіше художники працювали з О. Герою, Б. Вальком, Р. Жуком, І. Мацієвським, П. Думичем. Проте, траплялись і тандеми майстрів 3 досвідом. Таку бригаду наприкінці 70-х - поч. 80-х рр. формували два гутники-віртуози з багаторічним стажем Р. Жук і П. Думич, а у другій половині 80-х, поч. 90-х - Б. Валько і Р. Жук, які у співавторстві виконали декілька сотень зразків, у тому числі й склопосуду.

У проекті набору для пиття з арт. 6514, виконаному у 1980 р. у співавторстві Р. Жуком і П. Думичем, використаний традиційний спосіб прочісування кольорової шпіновки. Дотримана також класична форма квадратної карафки і циліндричних чарок. У наборі з арт. 6647 Р. Жук застосував мінімалістичний підхід до декору з використанням карбіду бору на зеленій основі виробу. При цьому лише легко підформована у керику банка глечика і склянки. Подібний прийом декорування у керику майстер застосував у комплекті з арт. 6733, додатково перекрутивши банку, створюючи враження перехресного декору. Основа виробу червоного напівпрозорого півтону. Додатково сформовані декоративні ручки з прозорих наліпів з обох боків карафки і з одного боку склянки.

Набагато насиченіший декор і продумана форма дзбанка у наборі до пиття, виконаному Р. Жуком і Б. Вальком у 1987 р. (арт. 8447). Видовжена форма глечика з простими стінками, які поступово звужуються від основи догори, доповнена горнятками, відформованими від руки. Прості ручки з базбарвного скла на дзбанку і горнятках. На білій основі всіх елементів набору накладена плутана нитка червоного кольору. Додатково у декількох місцях зроблено наклади у формі круглих плям заготовкою з грубої кольорової крихти. Цей набір можна вважати одним 
Деміург: ідеї, технології, перспективи дизайну № 2 (2018)

Demiurge: ideas, technologies, perspectives of design № 2 (2018)

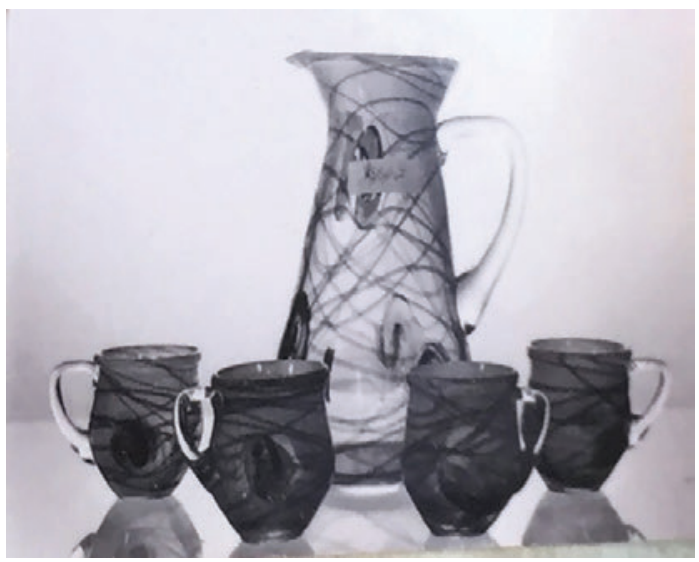

Рис. 4.6. Р. Жук, І. Чабан. Набір для пиття, ЛЕКСФ, 1987 р., арт. №8447. Гутне скло, вільне формування, $h=26 ; 8$ см. Фото з каталогу продукції ЛЕКСФ.

Fit. 4.6. R. Zhuk, I. Chaban. A set for drinking, LEXF, 1987, art. No.8,447. Gutna glass, free formation, $h=26 ; 8 \mathrm{~cm}$. Photo from the catalog of products LEXF.

з найбільш вдалих за поєднанням естетичних, функціональних і виробничих якостей. Доволі нескладний при виконанні декор позиціонує як зразок на місці бестселлерів свого часу завдяки ефектності, контрастності і виразності.

Значно складніші за формою і декором проекти І. Онищука, які за характером дещо претензійні і не завжди вирізняються пропорційністю і вишуканістю. Доволі дивна форма використана у дзбанку і горнятку з набору для пиття з арт. 5869. Додатково на форму, яка нагадує пісочний годинник, накладено спіраль з прозорого скла, декоративні наклади у місцях кріплення ручки. Ручка, до речі, також вигнута у не надто ерґономічну форму. Набагато простіший і естетичніший набір, виконаний художником у 1980 р., арт. 6239. Прості витягнуті рівностінні форми дзбанка і горнятка білого кольору декоровані відтягненими вертикальними червоними і коричневими лініями. Два наступні зразки декоровані грубими прозорими наліпами. При цьому, якщо в арт. 6570 наліпи виконують хоча б символічне функціональне призначення, оптично приклеюючи ручку до основи виробу, то в наборі з арт. 6741 вони ускладнюють форму і в певному сенсі обтяжують сприйняття. Перший набір виконаний у доволі важкій колористичній гамі з використанням смарагдового і медового скла. Другий, дещо легший, - чистий медовий.

М. Павловський при всій віртуозній майстерності не вдавався до ускладнення форми, а шукав способів досягнення естетичних вершин елементарними, але довершеними засобами. Проекти наборів посуду майстра - це простота у вишуканій версії з дотриманням кращих традицій народного гутництва. Часто дрібні малопомітні елементи ставлять акцент і насичують виріб характером. Як, наприклад, легкий і невимушений за формою і декором набір з арт. 5909, виконаний у 1979 р. з використанням мілефіорі на білій основі. Вишуканий глечик класичної форми з набору з арт. 5913 колористично витриманий у холодній гамі: біла основа виробу вкрита грубою відтягненою у двох місцях шпіновкою синього кольору. Тут варто звернути увагу на два елементи, які надають простим формам елегант- 
ності: темний ободок на звінченні обох складових набору і продута ручка на глечику.

До різних способів декорування і постійних пошуків форм вдавався упродовж десятиліть роботи на ЛЕКСФ І. Чабан. Майстер найчастіше застосовував декорування з допомогою насиченого кольорового внутрішнього декору. Зовнішні наліпи зустрічаються хіба що у зразках раннього періоду, у 1979-1980 рр. з арт. 5861 та 6022. Часами зустрічаємо доволі прості і легкі прозорі форми склопосуду, як у композиціях з арт. 6109, 6443 чи 6899. Проте, переважна більшість зразків, виконаних автором власноруч або у співавторстві, починаючи з 80-х рр., вирізняється характерним насиченим кольоровим декором з великими локальними плямами або грубою шпіновкою: арт. 6091, 6507, 6561, 6808, 6900, 6947, 6969, 7976. Окремо варто зупинитись на двох останніх зразках. Перший, де дзбанок виконаний у формі традиційного куманця, декорований насиченою, плутаною білою ниткою поверху безбарвної основи, покритої різнокольоровими великими плямами з накладеної грубої крихти. Другий, натомість, звертає на себе увагу завдяки геометризованій формі основи виробу, додатково збагаченій фігурними ручками, які підкреслюють гострі кути силуету. Декорована біла основа виробів великими плямами, накладеними заготовкою з кольорової крихти. Проте, якщо у вищеописаних зразках спостерігається певна системність у декоруванні, то три зразки раннього періоду вирізняються з загальної маси напрацювань Б. Валька. Це набори для пиття з арт. 5776, 5829, 6226. Тут здається, що декор є результатом або невдалого експерименту, або спонтанного рішення. У перших двох зразках була використана кольорова шпіновка з використанням техніки венеційської нитки, хоча це ледь прочитується. В останньому, натомість, декор настільки хаотичний, що важко спрецизувати техніку його виконання. Можливо, цей результат досягнено плутаною шпіновкою з грубою крихтою. Проте, повторити його у хоча б схожій конфіґурації було б неможливо.

Набір для пиття авторства Ф. Черняка з арт. 6725 вирізняється досконалим силуетом у доволі простій формі. Вишуканий

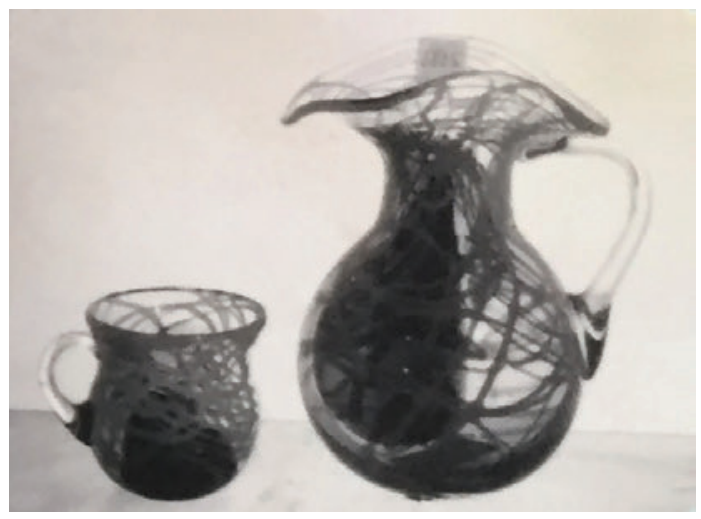

Рис. 4.7. Ф. Черняк, І. Чабан. Набір для пиття, ЛЕКСФ, 1982 р., арт. №6725. Гутне скло, вільне формування, $h=24 ; 9$ см. Фото з каталогу продукції ЛЕКСФ.

Fit. 4.7. F. Chernyak, I. Chaban. A set for drinking, LEXF, 1982, art. No.6725. Gutna glass, free formation, $h=24$; $9 \mathrm{~cm}$. Photo from the catalog of LEXF products. 
мінімалізм декору вдало доповнює формотворчі властивості композиції. Прозора основа виробу декорована однією великою темною плямою синього або зеленого кольору, по якій покладено плутану білу нитку. Форму дзбанка вирізняє широко розведена і вигнута верхня частина.

На фоні більшості продукції з класичними формальними ознаками вирізняються два зразки ілюстративного характеру. У роботі Є. Шимоняк-Косаковської «Фігура» з арт. 6649 елементарна форма напівпрозорого молочного кольору з дрібними бульбашками декорована зовнішнім фігурним накладом, зображаючи символічний пояс і вишиванку. Наліпи на корку формують, натомість, волосся і капелюх. Чарки також декоровані такими ж зовнішніми наліпами у підтримку композиції.

Іншим зразком з зовнішніми наліпами є штоф авторства київського художника О. Гущина, тиражований на базі ЛЕКСФ з нагоди ювілею м. Київ, арт. 6915. На тиходутій циліндричній формі виконані наліпи з печаткою, при цьому розміщені у відформованому посередині пляшки жолобі. Звінченням штофа $€$ корок, який шпичастою формою асоціативно наближує до золотоверхого Києва.

\section{Наукова новизна та практичне значення дослідження \\ 5}

Дослідження вперше в українському мистецтвознавстві комплексно розглядає формотворчі та технологічні особливості малотиражної гутної продукції вітчизняних скловиробників у контексті міжнародного руху студійного скла. Досі в мистецтвознавчій науці тема художнього скла, виконаного гутним способом, опрацьовувалась винятково в контексті діяльності професійних художників-склярів або майстрів-гутників і не розглядалась у площині функціонування як готового виробничого продукту.

Основні матеріали дослідження мають потенціал для подальшого вивчення українського гутництва кінця XX - початку XXI ст. у контексті міжнародного студійного руху.

Висновки 6 Друга половина XX ст. - період істотних і виразних змін в українському скловиробництві, доба розвитку напрямку декоративно-прикладного мистецтва - художнього скла. У його контексті яскраво вирізняється специфічна ланка - гутне скло, наділене характерними рисами національної самобутності. Принципово важливу роль у формуванні визначальних ознак львівського гутного скла цього періоду відіграли відроджені й розвинуті традиційні засоби формотворення, культивовані з покоління в покоління майстрами-гутниками. Водночас, над дизайном виробничих зразків гутної продукції ЛЕКСФ працювали й професійні художники, чия творча активність була скерована у двох напрямках - на створення авторських індивідуальних композицій та на проектування зразків для масового тиражування. Ці дві суттєво відмінні за характером ділянки творчості не могли не піддаватися взаємовпливові, завдяки 
чому асортимент виробів групи малотиражного декоративно-ужиткового скла упродовж 1970-1990 рр. значно розширився і змінився. Саме в цей період сформувався і утвердився в декоративно-прикладному мистецтві нашої країни важливий напрямок - дизайн гутного скла. Безперечно, безпосередній вплив на його формування мала діяльність таких непересічних особистостей, як А. Бокотей, Ф. Черняк, І. Аполлонов, А. Балабін, Л. Митяєва, О. Гущин, С. Мартинюк, Б. Галицький, З. Масляк, М. Павловський, Я. Мацієвський, О. Гера, П. Семененко, П. Думич та інші. Саме у виконаних цими митцями та майстрами-гутниками зразках проявляються основні тенденції дизайну продукції українських підприємств-виробників гутного скла цього періоду.

\section{Список посилань}

Корнієнко, Н. (1975). Українське гутне скло. Бібліотека українського мистецтва. Взято з http://uartlib.org/ukrayinske-gutne-sklo/.

Мартинюк, С. (2004). Давнє скло в Україні. В Д.М. Олійник (Ред.), Скло України (с. 176-196). Київ: Світ України.

Петрякова, Ф. (1975). Українське гутне скло. Київ: Наукова думка.

Станкевич, М. (2012). Протодизайн, концепції і морфологія дизайну. В М.І. Яковлєв (Ред.), Нариси з історії українського дизайну XX століття (с. 122-131). Київ: Фенікс.

Черняк, Ф. (2006). Львівське гутне скло другої половини XX століття: Нарис історії. Львів: ЛHAM.

\section{References}

Cherniak, F. (2006). Lvivske hutne sklo druhoi polovyny XX stolittia: Narys istorii [Lviv hut glass of the second half of the twentieth century: An essay on history]. Lviv: LNAM [in Ukrainian].

Korniienko, N. (1975). Ukrainske hutne sklo [Ukrainian hut glass]. Biblioteka ukrainskoho mystetstva [Library of Ukrainian Art]. Retrieved from http://uartlib.org/ukrayinske-gutne-sklo/ [in Ukrainian].

Martyniuk, S. (2004). Davnie sklo v Ukraini [Ancient glass in Ukraine]. In D.M. Oliinyk (Ed.), Sklo Ukrainy [Glass of Ukraine] (pp. 176-196). Kyiv: Svit Ukrainy [in Ukrainian].

Petriakova, F. (1975). Ukrainske hutne sklo [Ukrainian hut glass]. Kyiv: Naukova dumka [in Ukrainian].

Stankevych, M. (2012). Protodyzain, kontseptsii i morfolohiia dyzainu [Protodizain, concepts and morphology of design]. In M.I. Yakovliev (Ed.), Narysy z istorii ukrainskoho dyzainu XX stolittia [Essays on the history of Ukrainian design of the twentieth century] (pp. 122131). Kyiv: Feniks [in Ukrainian]. 